\title{
PERCEPTIONS OF INSTITUTIONAL TEACHING CULTURE BY TENURED, TENURE-TRACK, AND SESSIONAL FACULTY
}

\author{
DEBRA L. DAWSON \\ WESTERN UNIVERSITY
}

\author{
KENN. MEADOWS \\ WESTERN UNIVERSITY
}

\author{
ERIKA KUSTRA \\ UNIVERSITY OF WINDSOR
}

KATHRYND. HANSEN

ST.CLAR COLLEGE

\begin{abstract}
The Institutional Teaching Culture Perception Survey (ITCPS) was used to investigate beliefs of tenured, tenure-track, and sessional faculty members $(N=576)$ about the teaching culture within three large research-intensive universities in Canada. As predicted, we found significant differences between these three groups of faculty members' perceptions of their institutions' teaching cultures. Sessional faculty perceived that their universities rewarded effective teaching less than their tenured or tenure-track colleagues. Tenured faculty were less likely than the tenure-track and sessional faculty to believe it was important to encourage, recognize, or assess effective teaching. These results have important implications for the quality of teaching and, ultimately, student learning, as sessional faculty are teaching an increasing number of students and tenured faculty are the primary decision-makers in setting the priorities for their institutions.

Keywords: quality teaching, faculty appointments, post-secondary education, institutional teaching culture

\section{Résumé}

Un sondage portant sur la perception de la culture d'enseignement au niveau institutionnel a été utilisé pour enquêter sur les croyances des professeurs ayant un poste permanent, de ceux ayant un poste menant à la permanence et de ceux ayant un poste contractuel $(N=576)$ concernant la culture d'enseignement dans trois grandes universités de recherche au Canada. Comme nous nous y attendions, nous avons trouvé des différences importantes entre ces trois groupes de professeurs et leurs perceptions de la culture d'enseignement dans leurs établissements respectifs. Les professeurs ayant un poste contractuel ont moins ressenti que leur université récompensait l'enseignement efficace que leurs collègues ayant un poste permanent ou menant à la permanence. Les professeurs ayant la permanence ont eu moins tendance à croire qu'il était important d'encourager, de reconnaître ou d'évaluer l'enseignement efficace que ceux ayant un poste menant à la permanence ou un poste contractuel. Ces résultats ont des implications importantes sur la qualité de l'enseignement et, en fin de compte, sur l'apprentissage des étudiants, du fait que les professeurs contractuels enseignent à un nombre de plus en plus important d'étudiants, alors que les professeurs ayant la permanence sont les principaux décideurs quand il s'agit d'établir les priorités pour leur établissement.

Mots-clés : qualité de l'enseignement, nominations au corps professoral, études postsecondaires, culture pédagogique en établissement
\end{abstract}

\section{Introduction}

Sessional faculty members are increasingly being hired to teach undergraduate and graduate courses at post-secondary institutions across Canada and the United States (Brownlee, 2015; MacDonald, 2013; Webber \& Rogers, 2018). These faculty members often have very different conditions of employment than their tenured or tenure-track peers including less job security, lower pay, and fewer job benefits (Webb, Wong, \& Hubball, 2013). We believe that these often precariously employed faculty at research-intensive universities likely have a different perception of institutional teaching culture than their tenured or tenure-track colleagues and this is the focus of our study. As institutional teaching culture has been found to be related to student outcomes such as persistence, learning, and engagement (Berger \& Braxton, 1998; Berger \& Milem, 2000; Grayson \& Grayson, 2003), 
and as sessional faculty are teaching increasing numbers of students, differences across faculty appointments in perceptions of institutional teaching culture could ultimately have meaningful consequences for our students.

\section{Institutional Teaching Culture}

Research since the 1990's has suggested that creating a teaching culture within universities that values quality teaching is important both to motivate faculty members to enhance their teaching excellence (Feldman \& Paulsen, 1999) and to create an environment that leads to student success (Cox, McIntosh, Reason, \& Terenzini, 2011). Quality teaching which involves the use of pedagogical strategies that facilitate the achievement of student learning outcomes depends on supports at many levels, from policies at the institutional level that focus on pedagogical excellence to programs or initiatives that serve to enhance student learning at the instructor level (Hénard \& Roseveare, 2012). An institution's teaching culture then is the embedded patterns, behaviours, shared values, beliefs, and ideologies that indicate that the importance of teaching is recognized and valued at an institution. An effective institutional teaching culture recognizes the importance of teaching, constructively assesses teaching, engages various stakeholders and resources, and supports teacher development (Hénard \& Roseveare, 2012; Paulsen \& Feldman, 1995).

Furthermore, an institution's teaching culture can be observed through examining common indicators of teaching quality. This includes institutional processes, resources, and materials dedicated to enhancing the quality of teaching (Hénard \& Roseveare, 2012). For example, indicators related to an institution's strategic commitment to quality teaching include the presence of institutional strategic documents and initiatives that prioritize effective teaching. Indicators that an institution recognizes and rewards teaching would include the use of multiple measures to assess teaching (Dennin et al., 2017; Kustra et al., 2014).

Quality teaching is critical today given the need for graduates who are technologically savvy and workforce ready, with strong soft skills such as the ability to work well on teams (Bortz, 2018; Hess, 2019). As the role of post-secondary education changes to meet these demands so does the role of faculty members, such that both the senior administration and individual faculty members must be nimble in developing and implementing relevant and innovative curriculum (Hénard \& Ros- eveare, 2012). Cox et al. (2011) theorized that when university administrators try to cultivate a high-quality teaching culture they encourage learning centered pedagogical practices such as active and collaborative learning, which have been found to have a positive impact on student learning (Kilgo, Sheets, \& Pascarella, 2015). Furthermore, quality teaching cultures place a greater emphasis on both the assessment of effective teaching and teaching excellence (Feldman \& Paulsen, 1999). For instance, Cox et al.'s research found that a high-quality teaching culture led to increased student-faculty interaction outside the classroom, which is also a practice associated with greater student success (Kim \& Sax, 2014; Kuh, Kinzie, Schuh, \& Whitt, 2011).

There is a strong positive relationship between the quality of teaching and the institutional teaching culture (Stein, 1997). This is a complex relationship, but it is likely that an institution's teaching culture impacts professors' behaviours in the classroom. Therefore, improving the culture of teaching can affect the quality of education that students receive (Cox, et al., 2011; Feldman \& Paulsen, 1999).

Since the mid-sixties, organizational cultures in universities in Canada and the United States have shifted so that research, rather than teaching, is the primary institutional focus (Bak \& Kim, 2015; Clark, Moran, Skolnick, \& Track, 2009). This shift in focus has had a negative impact on the collective institutional teaching culture, as teaching is not valued as much as research. Bak and Kim (2015) found that faculty members are more likely to be motivated to enhance teaching excellence and support student learning in an environment that has an institutional culture that prioritizes quality teaching. As Goff (2015) concludes:

The development of a campus culture that values the institution's function in student learning and quality teaching would benefit from Enhancing Quality approaches to quality assurance. This would require holistic consideration of the beliefs held by members of the institution, a clear articulation of the institution's conceptions of quality, and a critical analysis of how these conceptions align with institutional practices and policies. (pp. ii-iii)

\section{Sessional Faculty}

Quite clearly, faculty members are essential for creating quality teaching and for fostering the institutional teach- 
ing culture both in their roles as senior administrators within the university and as instructors in the classroom (Hénard \& Roseveare, 2012). Yet, faculty members who teach at universities are not a homogeneous group in terms of employment. They may be hired into full-time tenured, tenure-track, or sessional positions. We use the term sessional to refer to those in neither tenured nor tenure-track faculty positions. Canadian institutions vary in their terminology, using terms such as contract, adjunct, limited-term, and non-full-time instructors, among others (Field, Jones, Karram Stephenson, \& Khoyetsyan, 2014; Osborne, Carpenter, Burnett, Rolheiser, \& Korpan, 2014).

Within Canadian postsecondary institutions up to $40 \%$ of the undergraduate courses are taught by sessional faculty (MacDonald, 2013). Although they make up a sizeable minority of post-secondary teachers, their impact on students may be larger than this percentage suggests as they tend to teach large enrollment courses (Clark, et al., 2009).

The conditions of employment vary dramatically between tenured or tenure-track and sessional positions (MacDonald, 2013). Research suggests that sessional faculty are often marginalized within their institutions (Johnson, 2011; Webb, Wong, \& Hubball, 2013). Perhaps not surprisingly, although sessional faculty members are satisfied with their work, research suggests they are far less satisfied than tenured or tenure-track colleagues with their work environments (Ryan, Groen, McNeil, Nadolny, \& Bhattacharyya, 2011). If teaching culture reflects the members' beliefs and ideologies about their educational institution (Kezar \& Eckel, 2002), it is likely that sessional faculty who feel less valued within the institution may have a different view of the teaching culture within their workplaces than their tenured or tenure-track colleagues.

\section{Changing Expectations}

Hénard and Roseveare (2012) regarded quality teaching as essential for ensuring student learning outcomes and considered both students and potential employers as key stakeholders in defining what those learning outcomes should be. They suggested that for quality teaching to be successfully implemented, buy-in is required at the individual, program, and institutional level. Buy-in at these levels would be made visible by having a teaching and learning centre, teaching awards, supports for innovation in teaching, and funding for innovative pedagogies. Also, Hénard and Roseveare stated that institutional policies and practices that support high-quality teaching and learning have become increasingly important due to a variety of factors, including a more diverse student body with the emphasis on internationalization on most campuses, rapid change in technological innovations in society and the classroom, and increased pressure to be responsive to employer needs. These same pressures are evident in Canada with the increasing number of non-traditional students (Glauser, 2018), increased emphasis on internationalization (Knight-Grofe \& Rauh, 2016; Universities Canada, 2014), and a focus on integrating technological innovations in the classroom (Johnson, Becker, Cummins, Estrada, Freeman, \& Hall, 2016).

As the outcomes expected by stakeholders from higher education change, so have faculty roles. These changes may have even greater implications for sessional faculty than for their tenured and tenure-track colleagues as sessional faculty are not as likely to be integrated into their institutions, and therefore may be less aware of changing expectations for their teaching at their institutions (MacDonald, 2013). MacDonald (2013) suggested that this may be because they are often hired just prior to the start of courses, may teach at multiple institutions, are less likely to be allowed to serve on departmental committees, and often have fewer rewards for outstanding teaching. This leaves sessional faculty feeling less valued as members of the academic community.

\section{The Current Study}

Based on an Institutional Management in Higher Education (IMHE) guide that examined higher education policies and procedures that support quality teaching (Hénard \& Roseveare, 2012), we developed the Institutional Teaching Culture Perception Survey (ITCPS-F) to examine faculty members' perceptions of their institution's teaching culture (Kustra et al., 2014). While cultures can vary within areas, such as within departments (Mårtensson \& Roxå, 2016a), there is also an overall culture, and the current survey focused on the larger teaching culture at the institutional level. This survey represented a significant step forward from previous research such as Cox et al. (2011) who attempted to measure faculty perceptions of a multidimensional construct, teaching culture, using short unidimensional measures. Cox et al. (2011) also did not examine possible variability between tenured, tenure-track, and sessional faculty members' perceptions of the teaching culture. Finally, although Canadian universities are seldom exclusively undergraduate 
institutions (Universities Canada, 2018), undergraduate institutions were the primary focus of their investigation, and most of the policy measures they examined related to the first-year experience, such as providing first-year students with experiential learning opportunities or examining their persistence into second year.

Using this newly developed survey, we investigated the value that tenured, tenure-track, and sessional faculty members perceived their institutions place on teaching (i.e., their institutional teaching culture). Given the research on the differences in work conditions between sessional faculty and their tenured and tenure-track colleagues (e.g., MacDonald, 2013; Tarr, 2010), we hypothesized that sessional faculty members would be less likely to think that their institutions placed value on teaching, and that they would assign more importance to valuing indicators of quality teaching than their tenured and tenure-track colleagues. We also predicted that tenured-faculty members would assign less importance to their institution valuing teaching than their tenure-track and sessional colleagues because of the emphasis placed on research in promotion decisions, whereas, for tenure-track faculty both teaching and research are weighted into tenure decisions, so teaching is still of importance at this career stage. Through this research, we intend to gain deeper insight into the differential percep- tions of teaching culture that faculty members have and, as a result, develop strategies for improving the teaching culture for all who teach at universities.

\section{Method}

\section{Participants}

Five-hundred and seventy-six tenured, tenure-track, and sessional faculty members from three large research-intensive universities in Southwestern Ontario participated in the research. Tenured faculty members at these institutions have traditional workloads of $40 \%$ research, $40 \%$ teaching, and $20 \%$ service. Overall, 729 faculty members participated in the research, representing a $15.4 \%$ participation rate. Of these, only 576 self-identified as tenured, tenure-track, or sessional faculty members and, thus, were included in the analyses.

The majority of respondents self-reported as male (55\%); from the Faculties of Arts, Humanities, and Social Science; Science; or Health Sciences (75\%); being tenured (51\%); and having 10 or more years of teaching experience $(72 \%)$. They were roughly equally distributed from across the three participating institutions (see Table 1).

Table 1. Distribution of Participants' Self-Reported Gender, Faculty, Primary Role, Appointment, Teaching Experience, and Institution.

\begin{tabular}{|c|c|c|}
\hline Demographic Variable & $n^{1}$ & Percentage \\
\hline \multicolumn{3}{|l|}{ Gender } \\
\hline Female & 252 & 44.9 \\
\hline Male & 307 & 54.7 \\
\hline Non-binary & 2 & 0.4 \\
\hline Total & 561 & 100 \\
\hline \multicolumn{3}{|l|}{ Faculty } \\
\hline Arts, Humanities, \& Social Science & 224 & 39.9 \\
\hline Business & 34 & 6.0 \\
\hline Education & 19 & 3.4 \\
\hline Engineering & 63 & 11.2 \\
\hline Health Sciences & 79 & 14.1 \\
\hline Law & 9 & 1.6 \\
\hline Science & 119 & 21.2 \\
\hline
\end{tabular}




\begin{tabular}{|c|c|c|c|}
\hline Demographic Variable & & $n^{1}$ & Percentage \\
\hline & Other & 15 & 2.7 \\
\hline & Total & 562 & 100 \\
\hline \multicolumn{4}{|l|}{ Primary Role } \\
\hline & Administrator & 15 & 2.6 \\
\hline & Assistant Professor & 72 & 12.6 \\
\hline & Associate Professor & 194 & 34.0 \\
\hline & Sessional Instructor & 96 & 16.8 \\
\hline & Full Professor & 142 & 24.9 \\
\hline & Lecturer & 36 & 6.3 \\
\hline & Other & 16 & 2.8 \\
\hline & Total & 571 & 100 \\
\hline \multicolumn{4}{|l|}{ Appointment } \\
\hline & Less than 1 year & 9 & 1.6 \\
\hline & 1 to 4 years & 55 & 9.6 \\
\hline & 5 to 9 years & 97 & 17.0 \\
\hline & 10 to 14 years & 133 & 23.3 \\
\hline & 15 to 19 years & 77 & 13.5 \\
\hline & 20 to 24 years & 67 & 11.7 \\
\hline & 25 to 29 years & 62 & 10.9 \\
\hline & $30+$ years & 71 & 12.4 \\
\hline & Total & 571 & 100 \\
\hline \multicolumn{4}{|l|}{ Institution } \\
\hline & 1 & 215 & 37.3 \\
\hline & 2 & 202 & 35.1 \\
\hline & 3 & 159 & 27.6 \\
\hline & Total & 576 & 100 \\
\hline
\end{tabular}

Note. ${ }^{1}$ Number of participants vary due to missing data.

\section{Measures}

\section{Demographics}

Participants completed six demographic items assessing their gender, faculty, primary role at the university, appointment type, years of teaching experience, and institution.

\section{Institutional Teaching Culture Perception Survey}

The faculty version of the Institutional Teaching Culture Perception Survey-(ITCPS-F; Kustra et al., 2014) is a 39-item questionnaire consisting of five categories of items (i.e., levers) designed to assess the extent to which participants agreed that certain indicators of a quality teaching culture were evident at their institutions and the importance that they placed on these indicators. 
Participants rated each item twice, once for agreement ( $1=$ strong disagree to $5=$ strongly agree) and once for importance $(1=$ not at all important to $5=$ very important).

To determine the structure of the ITCPS-F, we performed principal components analyses on the agreement and importance ratings separately. For the agreement ratings, four components were extracted. We calculated Cronbach's alphas for the components to determine their internal consistency; all four components evidenced good to excellent consistency. Based on an examination of the item loadings, we labelled the components Encouraging Effective Teaching, Broad Involvement around Teaching, Recognizing Effective Teaching, and Assessing Teaching (see Tables 2 and 3).

Table 2. Number of Participants, Number of Items, Cronbach's Alphas, Means, and Standard Deviations for the ITCPS-F Agreement and Importance Scales.

\begin{tabular}{cccccc}
\hline & $n^{1}$ & $\begin{array}{c}\# \\
\text { of items }\end{array}$ & $\alpha$ & Mean & $\begin{array}{c}\text { Std. } \\
\text { Deviation }\end{array}$ \\
\hline $\begin{array}{c}\text { Agreement Scales } \\
\text { Encouraging Effective Teaching }\end{array}$ & 343 & 16 & .92 & 2.89 & 0.798 \\
Broad Involvement around Teaching & $253^{3}$ & 11 & .89 & 2.96 & 0.766 \\
Recognizing Effective Teaching & 466 & 4 & .73 & 3.58 & 0.836 \\
Assessing Teaching & 415 & 6 & .79 & 2.57 & 0.823 \\
Importance Scales ${ }^{4} \quad$ & & & & & \\
Encouraging Effective Teaching & 383 & 17 & .94 & 3.80 & 0.724 \\
Recognizing Effective Teaching & 411 & 12 & .91 & 4.05 & 0.693 \\
Assessing Teaching & 414 & 10 & .89 & 3.98 & 0.668 \\
\hline
\end{tabular}

Note. ${ }^{1}$ Number of participants varied due to missing data. ${ }^{2}$ Two items which loaded on a fifth agreement scale were dropped from the analyses because they had a low Cronbach's alpha (i.e., .33). Participants rated their agreement from 1 (Strongly Disagree) to 5 (Strongly Agree). ${ }^{3}$ A substantially greater number of participants selected the "I prefer not to answer/l don't know" response for items on the Broad Involvement Around Teaching scale than items on the other agreement scales. This response was treated as missing data for all scales. ${ }^{4}$ Participants rated importance from 1 (Not at all Important) to 5 (Very Important).

Table 3. Definitions for the ITCPS-F Agreement and Importance Subscales.

\begin{tabular}{ll}
\hline Agreement Subscales & Definition \\
\hline Encouraging Effective Teaching & \\
& $\begin{array}{l}\text { The institution creates an environment that is supportive of } \\
\text { instructors engaging in high-quality pedagogical practices (e.g., } \\
\text { reflective practice, scholarly teaching). }\end{array}$ \\
Broad Involvement around Teaching & $\begin{array}{l}\text { Members of the institution and larger community are involved in } \\
\text { initiatives that foster instructors' development as teachers. }\end{array}$ \\
Recognizing Effective Teaching & Teaching excellence is acknowledged. \\
Assessing Teaching & Teaching effectiveness is evaluated.
\end{tabular}




\begin{tabular}{ll}
\hline & Definition \\
\hline Importance Subscales & \\
\hline Encouraging Effective Teaching & $\begin{array}{l}\text { The institution creates an environment that is supportive of } \\
\text { instructors engaging in, and further developing, high-quality peda- } \\
\text { gogical practices (e.g., they are provided adequate resources and } \\
\text { support). }\end{array}$ \\
Teaching excellence is an institutional priority that is acknowl- \\
edged and rewarded by the institution. \\
Assessing Teaching & $\begin{array}{l}\text { Teaching effectiveness is formally evaluated and self-evaluation } \\
\text { of teaching is encouraged. }\end{array}$ \\
\hline
\end{tabular}

(e.g., Human Resources) to all faculty members who were teaching a course in the winter 2014 term. Interested participants were entered into a draw for one of 36 $\$ 500$ gift cards (12 for each of the three institutions). Participants' email addresses and survey responses were stored in discrete databases to maintain confidentiality.

The research was submitted to and reviewed by each participating institution's Human Research Ethics Board.

\section{Data Analysis}

To examine appointment differences (i.e., differences between tenured, tenure-track, and sessional faculty) in the four agreement and three importance subscales of the ITCPS-F, we performed a series of one-way analysis of variance (ANOVAs). To control for the possible influence of years of teaching experience, we conducted a series of hierarchical multiple regressions with years of teaching experience entered on the first step and appointment type on the second. The results of the regressions are consistent with the reported results of the ANOVAs.

Because of the large number of participants who completed the survey, it was possible that even a very small difference could be statistically significant. To address this issue, we calculated effect sizes to determine if the statistically significant differences are substantive in size. For the ANOVAs, the effect size we report is etasquared. For eta-squared, Cohen (1988) indicates that an effect size of .02 is small, .13 is medium, and .26 is large.

To control for the inflation of Type 1 error (i.e., the likelihood of incorrectly finding a significant effect) due to multiple comparisons, we performed a Bonferroni correction. For the four agreement subscales, we set the $p$ value at $0.0125(.05 / 4)$ whereas for the three importance subscales we set it at $0.0167(.05 / 3)$.

When there are large differences in the number of participants in the groups as is the case with the numbers of tenured, tenure-track, and sessional faculty members in this research, ANOVAs are susceptible to violations of the assumption of homogeneity of variance. Where there are violations of this assumption, as assessed using Levene's test for equality of variances, we performed separate independent $t$-tests instead of ANOVAs. For the effect sizes for the $t$-tests, we report Cohen's (1988) $d$. For $d$, Cohen (1988) indicates that an effect size of .20 is small, .50 is medium, and .80 is large.

\section{Results}

\section{Agreement Ratings}

There was a significant difference for only one of the four agreement scales. Participants differed significantly in their ratings of the Recognizing Effective Teaching scale of the ITCPS- $F[F(2,463)=13.3, p<.001$, eta-squared $=.05]$. Specifically, sessional faculty members were less likely to agree that their institution recognized effective teaching than their tenured $[(t(410)=4.43, p<.001, d=$ $.49)$ and tenure-track $[t(172)=4.38, p<.001, d=.71]$. colleagues. Tenured and tenure-track faculty were not significantly different $[t(344)=-1.72, n s ., d=-.25]$

There were no significant differences based on appointment type for the other three agreement scales. For Broad Involvement around Teaching, the three groups of faculty members did not differ significantly $[F(2,250)$ $=0.464$, ns. eta-squared $=.004]$. For Encouraging Effective Teaching, and Assessing Teaching, there were 
violations of the assumption of homogeneity of variance [for Levene's test for equality of variances, $F(2,340)=$ $4.15, p=.017$ and $F(2,412)=8.25, p<.001$, respectively]. To address this issue, we performed a series of independent t-tests to examine appointment differences. None of these contrasts were significant. Tenured faculty members were no different in their ratings of Recognizing Effective Teaching and Assessing Teaching than their tenure-track $[\mathrm{t}(256)=-2.00, \mathrm{~ns} ., \mathrm{d}=-.25 ; \mathrm{t}(58)=-1.86$, ns., $d=-.49$ ] and sessional [t(129) $=-0.37$, ns., $d=-.07$; $t(155)=-1.47$, ns., $d=-.24]$ colleagues. Tenure-track and sessional groups did not differ on these ratings either $[t(122)=1.27$, ns., $d=.23$; $t(151)=.78, n s ., d=.13$; see Table 4]. tive Teaching $[F(2,380)=17.95, p<.001$; eta-squared $=$ .09]. Tenured faculty members rated Encouraging Effective Teaching of lesser importance than their tenure-track $[(t(274)=-2.50, p=.013, d=-.42]$ and sessional $[(t(335)$ $=-5.80, p<.001, d=-.70]$ counterparts. Tenure-track and sessional faculty were not significantly different $[t(151)=$ $-1.66, n s ., d=-.30$ ] (see Table 5).

Table 4. Descriptive Statistics for the ITCPS-F Agreement Scales for Tenured, Tenure-track, and Sessional Faculty Members.

\begin{tabular}{clccc}
\hline & & $n^{1}$ & Mean $^{2}$ & $\begin{array}{c}\text { Std. } \\
\text { Deviation }\end{array}$ \\
\hline Agreement Subscales & & & & \\
& Tenured faculty & 219 & 2.85 & .722 \\
Encouraging Effective Teaching & Tenure-track & 39 & 3.12 & .958 \\
& Sessional & 85 & 2.89 & .893 \\
& Tenured faculty & 157 & 2.96 & .746 \\
Broad Involvement around Teaching & Tenure-track & 28 & 3.09 & .864 \\
& Sessional & 68 & 2.92 & .775 \\
& Tenured faculty & 292 & 3.66 & .806 \\
& Tenure-track & 54 & 3.87 & .887 \\
& Sessional & 120 & 3.27 & .802 \\
& Tenured faculty & 262 & 2.50 & .726 \\
& Tenure-track & 49 & 2.78 & 1.008 \\
& Sessional & 104 & 2.65 & .935 \\
\hline
\end{tabular}

Note. ${ }^{1}$ Number of participants varied due to missing data. ${ }^{2}$ Participants rated their agreement from 1 (Strongly Disagree) to 5 (Strongly Agree).

\section{Importance Ratings}

There were significant differences based on appointment type for all three importance scales, with tenured faculty rating all three scales as less important than tenure-track and sessional instructors, who did not differ significantly from one another. Specifically, there was a significant difference for the importance rating of Encouraging Effec-
For Recognizing Effective Teaching and Assessing Teaching, there were violations of the assumption of homogeneity of variance [for Levene's test for equality of variances, $F(2,408)=7.37, p=.001$ and $F(2,411)=8.02$, $p<.001$, respectively]. The t-tests we performed demonstrated that tenured faculty members rated Recognizing Effective Teaching and Assessing Teaching of lesser importance than their tenure-track $[t(100)=-3.01, p=.003$, 
Table 5. Descriptive Statistics for the ITCPS-F Importance Scales for Tenured, Tenure-track, and Sessional Faculty Members.

\begin{tabular}{llccc}
\hline & & $n^{1}$ & Mean & $\begin{array}{c}\text { Std. } \\
\text { Deviation }\end{array}$ \\
\hline Importance Subscales & & & & \\
& Tenured faculty & 230 & 3.63 & .725 \\
Encouraging Effective Teaching & Tenure-track & 46 & 3.92 & .639 \\
& Sessional & 107 & 4.11 & .646 \\
& Tenured faculty & 246 & 3.92 & .752 \\
& Tenure-track & 51 & 4.18 & .516 \\
& Sessional & 114 & 4.29 & .545 \\
& Tenured faculty & 250 & 3.80 & .707 \\
& Tenure-track & 49 & 4.23 & .441 \\
& Sessional & 115 & 4.25 & .527 \\
\hline
\end{tabular}

Note. ${ }^{1}$ Number of participants varied due to missing data.

$d=-.60 ; t(104)=-5.50, p<.001, d=-1.08]$ and sessional $[t(295)=-5.27, p<.001, d=-.61 ; t(290)=-6.71, p<.001$, $d=-.79]$ colleagues. Tenure-track and sessional did not differ on these importance ratings $[t(163)=-1.20, n s ., d=$ -.19 and $t(162)=-.25, n s ., d=-0.04]$.

\section{Discussion}

As predicted, we found there were significant differences between tenured, tenure-track, and sessional faculty members in how they perceived the teaching cultures at their institutions. Specifically, the tenured and tenure-track faculty were more likely to agree that their institutions rewarded effective teaching than their sessional colleagues. This is not surprising given that sessional faculty are typically paid less, have fewer employment benefits, and may not even have a separate office (Field et al., 2014). Also, many institutions in Canada have separate awards for sessional faculty and may exclude them from applying for some teaching awards. Further, as many sessional faculty members teach at multiple institutions, they may be less aware of the ways that their institutions recognize and support good teaching (e.g., appointment of teaching fellows).

Contrary to our predictions, no differences were evident between the three faculty groups in assessing teaching, encouraging effective teaching, and broad involvement in teaching (i.e. the other three agreement subscales). The agreement ratings subscales of the ITCS-F measure the extent to which faculty agreed that specific indicators of quality teaching were present at their institutions. We believe that one reason for the similarity between these three groups may be that, unlike rewarding effective teaching, as educators all three groups observe similar institutional indicators in these areas. For instance, there is a common institutional strategic plan and teaching effectiveness is assessed in a similar manner, regardless of appointment type. It may be that for assessing teaching, encouraging effective teaching, and broader involvement in teaching, universities have done a better job of leveling the playing field for the three groups of faculty members than they have for rewarding effective teaching.

More disconcerting for us is that based on the mean scores on these three subscales, all faculty were neutral, neither agreeing nor disagreeing that these indicators were evident at their institutions. For quality teaching to occur, Hénard and Roseveare (2012) believe that it is important these indicators of quality teaching are prioritized. We would have hoped to see a stronger agreement that these indicators of quality teaching are present at every level of the professoriate.

Our hypotheses were partially supported in terms of appointment differences in importance of the teaching culture indicators. Supporting our prediction, tenured faculty consistently gave lower importance ratings than 
their sessional and tenure-track colleagues. Contrary to our prediction, there were no differences between tenure-track and sessional faculty in importance ratings. That is, tenured faculty were less likely than their colleagues to believe it is important for their universities to place a high value on encouraging, recognizing, and assessing effective teaching. This may reflect the importance placed on research output as opposed to teaching at most research-intensive universities, particularly after tenure has occurred (Bak \& Kim, 2015). At least at the promotion and tenure stage most universities place some value on effective teaching, yet promotion is often primarily focussed on the quality of research in the discipline (Dennin et al., 2017). Dennin et al. (2017) also stated that institutions with strong quality teaching cultures have department chairs who value and reward effective teaching and emphasize the role of teacher as integral to the role of faculty as scholars. Without such incentives, tenured faculty are less likely to be motivated to enhance their own teaching excellence and are more likely to focus their resources on research (Bak \& Kim, 2015).

There are micro-cultures within and between departments and faculties and disseminating messages from senior leadership to individual departments can help facilitate more conversations around-and emphasis onteaching and educational development (Major \& Palmer, 2006; Mårtensson \& Roxå 2016b). Often these discussions are critical from a social learning perspective for individual faculty members to develop the social networks where discussions about teaching and learning can occur (Kenbow \& Lee, 2019; Wright, 2005). Kenbow and Lee (2019) stress these discussions are critical as they lead to improved professional practice of teaching and therefore influence student learning outcomes. If faculty are not in a supportive environment where discussions around learning are likely to take place, there may be a negative effect on implementing changes to enhance institutional teaching culture. Lack of support by tenured faculty for teaching related discussions will do little to enhance these crucial conversations.

In addition, as it is the tenured faculty who are the primary institutional decision makers within their universities (Jones, 2013), including hiring, tenure, and promotion decisions, the value they perceive their institution places on teaching is likely to influence how they allocate resources. This can impact any changes that might be made to enhance teaching quality such as investing in innovative pedagogies. Individuals who do not believe their teaching is valued by their institutions are not likely to be concerned with enhancing their teaching effectiveness or making significant teaching related contributions to their universities (Bak \& Kim, 2015). Dennin et al. (2017) provide ideas for how we can shift the culture towards one that values both high quality teaching and research such as providing clear signals that teaching is important including providing start up professional funds for teaching related activities and clear metrics on how teaching will be evaluated for new hires. The results of the current study would suggest taking such steps is essential if we wish to have quality teaching be more highly valued.

Tenured faculty have a large influence on the overall institutional culture and therefore, despite their large number, sessional faculty are in the wake of their tenured colleagues. Although both sessional and tenure-track faculty in our study had significantly higher importance ratings for encouraging, recognizing, and assessing effective teaching than that of tenured faculty, the challenge of involving sessional faculty in teaching development is ongoing. Field and Jones (2016) surveyed sessional faculty in 12 Ontario universities and found that when asked how the learning environment could be improved the sessional faculty requested more avenues to advance their pedagogical and technical skills through opportunities to access their teaching and learning centres. As many sessional faculty members teach online, off-campus, or at night, as well as often being employed outside of the university (Tarr, 2010), providing such opportunities will require additional resources. However, as sessional faculty they have little input into the budget allocations within their institutions and if a quality teaching culture is not highly valued it is unlikely those funding needs will be a priority.

\section{Implications of Findings}

The results of this study demonstrate that the beliefs about institutional teaching culture vary by appointment type within the university. As Cox et al. (2011) noted, institutional teaching culture is driven by the members of the culture having shared values. The results indicate that the tenured faculty have a somewhat different set of values than the tenure-track and sessional instructors. It is worth considering whether this is the result of the position level itself and the security of tenure or of the time period that the cohort was hired and the expectations as they entered higher education. If it is a difference due to 
their role, targeted effort with tenured faculty may be one area of focus when working on an institution's teaching culture (Dennin et al., 2017).

The results also indicate that for all three groups of educators there is a need to strengthen many of the institutional indicators that focus on teaching quality. One way that senior administrators can signal the importance of teaching is through the development of strategic plans that emphasize quality teaching and outline specific actions with mandatory deliverables to enhance teaching. One example of such a plan in Canada is the University of Calgary's Integrated Framework for Teaching and Learning (n.d.). The goal of the framework is to enhance student success by supporting a plan that leads to student engagement and deep learning through the development of teaching expertise. It is this type of plan that could have positive influence on shifting institutional teaching culture at many other institutions (University of Calgary, n.d.).

\section{Future Research}

Although the current research investigated tenure-track, tenured, and sessional faculty, these are not necessarily homogenous groups. For example, tenured and tenure-track faculty who are hired into traditional faculty workloads may perceive their institutions' teaching cultures differently than those hired into teaching stream positions. Similarly, sessional faculty can differ in their reasons for engaging in part-time work; some are parttime for voluntary reasons, such as specialists who have a full-time career somewhere else, whereas others may be part-time faculty but would prefer full-time positions (Maynard \& Joseph, 2008; Tarr, 2010). Maynard and Joseph (2008) found that involuntary sessional academics had lower work satisfaction than their voluntary peers. These differences may impact their perceptions of the teaching culture. Similarly, future research could move beyond faculty roles to examine how demographic variables such as gender, racial, and/or discipline differences may exist in faculty's perception of their institution's teaching culture.

Finally, it will be important to determine differences in teaching culture based on the type of institution. The teaching culture is undoubtedly different in predominantly teaching institutions than in research-intensive universities like those in the present study, both of which may differ from the teaching culture at colleges and CEGEPs. To have a fuller understanding of faculty members' per- ceptions of teaching culture it will be important to examine differences within appointment types, demographics, and institution types.

\section{Conclusion}

The results of our study extend previous research by examining how faculty with different appointments perceive their university's teaching culture using a comprehensive measure of institutional teaching culture. We found that tenure-track and tenured faculty were more likely to believe that their university recognized and rewarded effective teaching than sessional faculty, and tenured faculty were likely to perceive recognizing, assessing, or encouraging effective teaching as less important compared to their tenure-track and sessional colleagues. As tenured faculty are the principal decision-makers within universities, it seems unlikely that significant resources will be allocated to improving the teaching culture within their universities without their support. In addition, sessional faculty are not as likely to feel a sense of belonging at their universities if their contributions to the institution are not valued or rewarded. Given the increasing number of sessional faculty within our higher education institutions, it is important to ensure that substantial effort is spent developing and sustaining the teaching culture. Finally, as teaching culture is critically related to student learning, it is essential that we continue to investigate teaching culture within higher education and how changes in practices can lead to a teaching climate that is valued by all faculty.

\section{Acknowledgements}

We would like to thank Paola Borin, Donna Ellis, Lori Goff, Jill Grose, Sandy Hughes, Peter Wolf, Florida Doci, Catharine Dishke Hondzel, Lindsay Shaw, Samantha Burton, Carly Del Pup, Hoda Eiliat, Danielle Gabay, Kaitlyn Gillard, Rebeca Lee, Gayle McIntyre, Karyn Olsen, Naseem Sherwani, Abeer Siddiqui, and Melec Zeadin for their contributions to the project. We are also extremely grateful to the faculty members from the three participating universities for sharing their perspectives on institutional teaching culture. This research was supported by the Social Sciences and Humanities Research Council of Canada (SSHRC) and the Productivity Innovation Fund (PIF), Ontario Ministry of Training, Colleges and Universities. 


\section{References}

Bak, H., \& Kim, D. H. (2015). Too much emphasis on research? An empirical examination of the relationship between research and teaching in multitasking environments. Research in Higher Education, 56, 843-860, https://doi.org/10.1007/s11162-015-9372-0

Berger, J. B., \& Braxton, J. M. (1998). Revising Tinto's interactionalist theory of student departure through theory elaboration: Examining the role of organizational attributes in the persistence process. Research in Higher Education, 39(2), 103-119. https:// doi.org/10.1023/A:1018760513769

Berger, J. B., \& Milem, J. F. (1999). The role of student involvement and perceptions of integration in a causal model of student persistence. Research in Higher Education, 40(6), 641-664. https://doi. org/10.1023/A:1018708813711

Bortz, D. (2018). These seven job skills can make you more marketable to employers. Retrieved from https://www.monster.com/career-advice/article/ work-skills-2018-1217

Brownlee, J. (2015). Contract faculty in Canada: Using access to information requests to uncover hidden academics in Canadian universities. Higher Education, 70(5), 787-805. https://doi.org/10.1007/ s10734-015-9867-9

Clark, I., Moran, G., Skolnik, M. L., \& Trick, D. (2009). Academic transformation: The forces reshaping higher education in Ontario. Kingston, ON: Queen's University School of Policy Studies and McGill-Queen's University Press.

Cox, B. E., Mclntosh, K. L., Reason, R. D., \& Terenzini, P. T. (2011). A culture of teaching: Policy, perception, and practice in Higher Education. Research in Higher Education, 52, 808-829. https://doi. org/10.1007/s11162-011-9223-6

Dennin, M., Schultz, Z. D., Feig, A., Finkelstein, N., Greenhoot, A. F., Hildreth, M., Leibovich, A. K., Martin, J. D., Moldwin, M. B., O'Dowd, D. K., Posey, L. A., Smith, T. L. \& Miller E. R. (2017). Aligning practice to policies: Changing the culture to recognize and reward teaching at research universities. CBE- Life Sciences Education, 16(5), 1-8. https:// doi.org/10.1187/cbe.17-02-0032

Feldman, K. A., \& Paulsen, M. B. (1999). Faculty motivation: The role of a supportive teaching culture. New Directions for Teaching and Learning, 78, 69-78. https://doi.org/10.1002/tt.7807

Field, C. C., \& Jones, G. A. (2016). A survey of sessional faculty in Ontario publicly-funded universities. Toronto, ON: Centre for the Study of Canadian and International Higher Education, OISE-University of Toronto.

Field, C. C., Jones, G. A., Karram Stephenson, G., \& Khoyetsyan, A. (2014). The "other" university teachers: Non-full-time instructors at Ontario universities. Toronto, ON: Higher Education Quality Council of Ontario. Retrieved from http://www.heqco.cal en-ca/Research/ResPub/Pages/The-Other-University-Teachers-Non-Full-Time-Instructors-at-Ontario-Universities.aspx

Glauser, W. (2018, August 1). Universities make way for the "non-traditional" student. Retrieved from https:/l www.universityaffairs.ca/features/feature-article/ make-way-for-the-non-traditional-student/

Goff, L. (2015). Conceptions of quality and approaches to quality assurance in Ontario's universities (Unpublished doctoral dissertation). Brock University, St. Catharines, Canada.

Grayson, J. P., \& Grayson, K. (2003). Research on retention and attrition. Montreal, QC: The Canadian Millennium Scholarship Foundation.

Hénard, F., \& Roseveare, D. (2012). Fostering quality teaching in higher education: Policies and practices - An IMHE guide for higher education institutions. Paris, France: Organisation for Economic Co-operation and Development. Retrieved from https:/l www.oecd.org/education/imhe/QT\%20policies $\% 20$ and\%20practices.pdf

Hess, A. (2019, January 6). The 10 most in-demand skills of 2019, according to LinkedIn. Retrieved from https://www.cnbc.com/2019/01/04/the-30-most-indemand-skills-in-2019-according-to-linkedin-.html

Johnson, I. Y. (2011). Contingent instructors and student outcomes: An artifact or a fact. Research in Higher Education, 52, 761-785. https://doi.org/10.1007/ 


\section{s11162-011-9219-2}

Johnson, L., Adams Becker, S., Cummins, M., Estrada, V., Freeman, A., \& Hall, C. (2016). NMC horizon report: 2016 higher education edition. Austin, TX: The New Media Consortium. Retrieved from http://cdn. nmc.org/media/2016-nmc-horizon-report-he-EN.pdf

Jones, G. A. (2013). The horizontal and vertical fragmentation of academic work and the challenge for academic governance and leadership. Asia Pacific Education Review, 14(1), 75-83. https://doi. org/10.1007/s12564-013-9251-3

Kenbow, R. J., \& Lee, C. (2019). Teaching-focused social networks among college faculty: Exploring conditions for the development of social capital. Higher Education, 78, 67-89. https://doi.org/10.1007/ s10734-018-0331-5

Kezar, A. J., \& Eckel, P. D. (2002). The effect of institutional culture on change strategies in higher education: Universal principles or culturally responsive concepts? The Journal of Higher Education, 73(4), 435-460. https://doi.org/10.1080/00221546.2002.1 1777159

Kilgo, C. A., Sheets, J. K. E., \& Pascarella, E. T. (2015). The link between high-impact practices and student learning: Some longitudinal evidence. Higher Education, 69(4), 509-525. https://doi.org/10.1007/ s10734-014-9788-Z

Kim, Y. K., \& Sax, L. J. (2014). The effects of student-faculty interaction on academic self-concept: Does academic major matter? Research in Higher Education, 55, 780-809. https://doi.org/10.1007/ s11162-014-9335-X

Knight-Grofe, J., \& Rauh, K. (2016). A world of learning: Canada's potential and performance in international education. Ottawa, ON: Canadian Bureau for International Education. Retrieved from https://cbie.cal wp-content/uploads/2017/07/A-World-of-LearningHI-RES-2016.pdf

Kuh, G. D., Kinzie, J., Schuh, J. H., \& Whitt, E. J. (2011). Student success in college: Creating conditions that matter. Washington, DC: Jossey-Bass.

Kustra, E., Doci, F., Meadows, K. N., Dawson, D. L., Dishke Honzel, C., Goff, L., Wolf, P., Ellis, D.,
Grose, J., Borin, P., \& Hughes, S. (2014). Teaching culture indicators: Enhancing quality teaching. Report to the Ministry of Training, Colleges and Universities Productivity and Innovation Fund Program, Windsor, ON: University of Windsor. https://scholar. uwindsor.ca/ctlreports/5/

MacDonald, M. (2013, January 9). Sessionals, up close. Retrieved from http://www.universityaffairs.ca/features/feature-article/sessionals-up-close/

Mårtensson, K., \& Roxå, T. (2016a). Working with networks, microcultures and communities. In D. Baume \& C. Popovic (Eds.), Advancing practice In academic development (pp. 174-187). New York, NY: Routledge.

Mårtensson, K., \& Roxå, T. (2016b). Leadership at a local level - Enhancing educational development. Educational Management Administration and Leadership, 44(2), 247-262. https://doi. org/10.1177/1741143214549977

Maynard, D. C., \& Joseph, T. A. (2008). Are all part-time faculty underemployed? The influence of faculty status preference on satisfaction and commitment. Higher Education, 55(2), 139-154. https://doi. org/10.1007/s10734-006-9039-z

Osborne, B. J., Carpenter, S., Burnett, M., Rolheiser, C., \& Korpan, C. (2014). Preparing graduate students for a changing world of work. Canadian Journal of Higher Education, 44(3), i-ix.

Paulsen, M. B., \& Feldman, K. A. (1995). Taking teaching seriously: Meeting the challenge of instructional improvement. ASHE-ERIC Higher Education Report No. 2. Washington, DC: The George Washington University Graduate School of Education and Human Development.

Ryan, S., Groen, E., McNeil, K., Nadolny, A., \& Bhattacharyya, A. (2011). Sessional employment and quality in universities: A risky business. In K. Krause, M. Buckridge, C. Grimmer, \& S. Purbrick-Illek (Eds.), Research. and development in higher education: Higher education on the edge (Vol. 34, pp. 275-284). Milperra, Australia: Higher Education Research and Development Society of Australasia. 
Stein, J. (1997). How institutions learn: A socio-cognitive perspective. Journal of Economic Issues, 31(3), 729-740. https://doi.org/10.1080/00213624.1997.1 1505962

Tarr, T. A. (2010). Working with adjunct faculty members. In K. J. Gillespie, D. L. Robertson, \& Associates (Eds.), A guide to faculty development (2nd ed., pp.347-362). San Francisco, CA: Jossey-Bass.

University of Calgary (n.d.). Integrated framework for teaching and learning. Retrieved from https://www. ucalgary.ca/provost/strategic-initiatives/integrated-framework-teaching-and-learning

Universities Canada (2014, December). Internationalization at Canadian universities: Quick facts. Retrieved from http://www. univcan.ca/wp-content/ uploads/2015/07/quick-facts-internationalization-survey-2014.pdf

Universities Canada (2018). Facts and stats: 2018 full-time and part-time fall enrolment at Canadian universities. Retrieved from https://www.univcan.cal universities/facts-and-stats/enrolment-by-universityl

Webber, K. L., \& Rogers, S. M. (2018). Gender differences in faculty member job satisfaction: Equity forestalled. Research in Higher Education, 59, 1105-1132 https://doi.org/10.1007/s11162-0189494-2

Weingarten, H. P. (2017, March 28). What is academic quality? Retrieved from http://blog-en.heqco. ca/2017/03/harvey-p-weingarten-what-is-academic-qualityl

Webb, A. S., Wong, T. J., \& Hubball, H. T. (2013). Professional development for adjunct teaching faculty in a research-intensive university: Engagement in scholarly approaches to teaching and learning. International Journal of Teaching and Learning in Higher Education, 25(2), 231-238.

Wright, M. (2005). Always at odds?: Congruence in faculty beliefs about teaching at a research university. The Journal of Higher Education, 76(3), 331-353. https://doi.org/10.1080/00221546.2005.11772285

\section{Contact Information}

Debra Dawson

dldawson@uwo.ca 